УДК 342.9

DOI https:/ / doi.org/10.32837/yuv.v0i1.1572

\author{
О. Вінницький, \\ кандидат юридичних наук, \\ доцент кафедри соціальних теорій \\ Одеського національного університету імені I.I. Мечникова
}

\title{
АКТУАЛЬНІ ПРОБЛЕМИ ДОКАЗІВ I ПРОЦЕСУ ДОКАЗУВАННЯ В АДМІНІСТРАТИВНОМУ СУДОЧИНСТВІ
}

\begin{abstract}
Забезпечення прав і свобод потребує, зокрема, законодавчого закріплення механізмів (процедур), які створюють реальні можливості для здійснення кожним громадянином прав і свобод. До таких механізмів належить структурована система судів і види судового провадження, установлені державою. Судовий захист уважається найбільш дієвою гарантією відновлення порушених прав і свобод людини та громадянина. Окрему думку щодо реалізації права на судовий захист в адміністративному судочинстві висловив суддя Конституційного Суду України, який зазначив, що «за адміністративним судочинством, на відміну від господарського та цивільного, преференції мають надаватися людині» [4]. Убачається, що така точка зору визначена тим, що особа й органи публічної адміністрації наділені різним адміністративно-правовим статусом, що, відповідно, установлює нерівність у їхніх правах і можливості захисту своїх прав.

Для захисту особи від діяльності органів виконавчої влади й органів місцевого самоврядування законодавством України передбачена діяльність саме адміністративних судів. Так, ч. 4 ст. 125 Конституції України визначено, що з метою захисту прав, свобод та інтересів особи у сфері публічно-правових відносин діють адміністративні суди.

Саме адміністративна юстиція має певну особливість у розподілі обов'язків доказування. Зазвичай доказування
\end{abstract}

покладалося на представника державного органу, проте законодавець змінив цю норму й тепер частково тягар доказування покладається на іншу сторону процесу, унаслідок чого підвищилася змагальність процесу адміністративного судочинства [10].

Розгляд і вирішення справ в адміністративних судах здійснюються на засадах змагальності сторін і свободи в наданні ними суду своїх доказів і в доведенні перед судом їх переконливості. Суд уживає визначені законом заходи, необхідні для з'ясування всіх обставин у справі, у тому числі щодо виявлення та витребування доказів з власної ініціативи [1, ст. 9].

Доказами в адміністративному судочинстві є будь-які дані, на підставі яких суд установлює наявність або відсутність обставин (фактів), що обгрунтовують вимоги й заперечення учасників справи, та інші обставини, що мають значення для правильного вирішення справи. Ці дані встановлюються такими засобами: 1) письмовими, речовими й електронними доказами; 2) висновками експертів; 3) показаннями свідків [1, ст. 72].

Також Кодекс адміністративного судочинства (далі - KАС) України встановлює вимоги, яким повинні відповідати докази: належність, допустимість, достовірність, достатність.

В.К. Колпаков і В.В. Гордєєв стверджують, що принцип офіційного з'ясування всіх обставин справи в низці норм КАC України забезпечується 
так: 1) визначає обставини, які необхідно встановити для вирішення спору, а також з'ясовує, якими доказами сторони можуть обгрунтовувати свої доводи чи заперечення щодо цих обставин (п. п. 3, 4 ч. 4 ст. 111 КАС Украіни); 2) пропонує особам, які беруть участь у конкретній справі, доповнити чи пояснити певні обставини справи, а також надати суду додаткові докази (ч. 5 ст. 11 , ч. 1 ст. 114 КАС Україн); 3) за власною ініціативою повинен виявити й витребувати докази, яких, на думку суду, не вистачає (ч. ч. 4, 5 ст. 11 , ч. 4 ст. 65, ч. 5 ст. 71 , п. 1 ч. 2 ст. 110 КАС України); 4) також може визнати обов'язкову участь у судовому засіданні сторони (чи сторін) або третьої особи, якщо виникне необхідність заслухати ї особисто (п. 2 ч. 2 ст. 110, ст. 120 КАС Украіни); 5) може визнати за необхідне дослідити докази щодо обставин, які визнаються сторонами, якщо в нього може виникнути сумнів щодо достовірності цих обставин і добровільності ix визнання (ч. 3 ст. 72 КАС Україн); 6) під час допиту свідка в суді може ставити йому питання в будьякий час, а не лише після закінчення допиту його особами, які беруть участь у справі, як це здійснюється в цивільному судочинстві (ч. 8 ст. 141 KAC України) [3, с. 93].

Особливе значення серед засобів захисту своїх прав відведено саме доказам і процесу доказування. Статтею 77 КАС України визначено, що в адміністративних справах про протиправність рішень, дій чи бездіяльності суб'єкта владних повноважень обов'язок щодо доказування правомірності свого рішення, дії чи бездіяльності покладається на відповідача. Водночас, незважаючи на те що обов'язок доказування покладено на відповідача, докази суду надають учасники справи. Суд може пропонувати сторонам надати докази та збирати докази з власної ініціативи. Суд не може витребовувати докази в позивача в адміністративних справах про протиправність рішень, дій чи бездіяльності суб’єкта владних повноважень, окрім доказів на підтвердження обставин, за яких, на думку позивача, відбулося порушення його прав, свобод чи інтересів [1].

Законодавець установив обов'язок саме суб'єкта владних повноважень подавати до суду всі наявні в нього документи й матеріали, які можуть бути використані як докази у справі. У разі невиконання цього обов'язку суд витребовує названі документи й матеріали, а якщо такі приписи відповідач без поважних причин не виконує, то суд вирішує справу на основі наявних доказів. Отже, адміністративні суди під час вирішення публічно-правових спорів наділені правом покласти виконання обов'язку на сторону під час вирішення справи та дослідження доказів [1].

Треба зауважити, що норми КАС України встановлюють, що в адміністративних справах про протиправність рішень, дій чи бездіяльності суб’єкта владних повноважень обов'язок щодо доказування правомірності свого рішення, дії чи бездіяльності покладається на відповідача. При цьому він особливо підкреслив, що в таких справах суб'єкт владних повноважень не може посилатися на докази, які не покладені в основу оскаржуваного рішення, за винятком випадків, коли він доведе, що ним ужито всіх можливих заходів для їх отримання до прийняття оскаржуваного рішення, але вони не отримані з незалежних від нього причин. До того ж суд не може витребовувати докази в позивача в адміністративних справах про протиправність рішень, дій чи бездіяльності суб'єкта владних повноважень, окрім доказів на підтвердження обставин, за яких, на думку позивача, відбулося порушення його прав, свобод чи інтересів. Якщо ж учасник справи без поважних причин не надасть докази на пропозицію суду для підтвердження обставин, на які він посилається, суд вирішує справу на підставі наявних доказів або в разі необхідності приймає рішення про витребування останніх $[10 ; 1]$. 
Із цього приводу наведено досвід Франції щодо характеру діяльності адміністративних судів. Так, визначаючи роль суду в адміністративному судочинстві Франції щодо забезпечення доказів, Ж. Ведель указує на слідчий характер діяльності судді, що проявляється в наданні суддею пропозиції адміністрації (органу влади, до якого звертаються з позовом) надати пояснення щодо суті справи та відповідні докази. У разі мовчання чи ненадання доказів це свідчить не на користь адміністрації [5, с. 326-327]. Г. Бребан визначає, що адміністративне судочинство Франції має інквізиційний характер, що проявляться в такому: 1) суд керує розглядом справи; 2) заявник не може повноцінно зібрати й надати докази, тому що це фізична особа, яка перебуває в гіршому становищі щодо збирання доказового матеріалу, що перебуває у віданні адміністраціі. Саме тому суддя вправі витребувати докази в адміністрації, керуючись своїми інквізиційними повноваженнями [6].

Схожу точку зору відстоюють i вітчизняні науковці Н.Г. Салищева та Н.Ю. Хаманева, акцентуючи увагу на необхідності суду в разі необхідності самостійно забезпечити надання доказів шляхом їх витребування в суб'єкта владних повноважень [7].

Подібної думки дотримуються українські науковці-адміністративісти І.Б. Коліушко, Р.О. Куйбіда, Н.В. Александрова щодо питання ролі судді в захисті прав особи й забезпечення доказів в адміністративному судочинстві, які відзначають, що суд повинен відіграти активну роль у судовому процесі, щоб сприяти особі в захисті іï прав. Тому суд має вжити всіх передбачених законом заходів, щоб порушені владою права були захищені [8; 9].

Отже, під час вивчення матеріалів справи адміністративний суд може з власної ініціативи витребувати докази, які не надані стороною відповідача, а позивач не має змоги самостійно їх отримати та надати суду [1].
Предметом доказування $є$ обставини, які підтверджують заявлені вимоги чи заперечення або мають інше значення для розгляду справи й підлягають установленню під час ухвалення судового рішення, то до обставин, що не підлягають доказуванню, зараховано преюдиційні обставини; обставини, які визнаються сторонами процесу; загальновідомі факти й безспірні обставини (обставини, установлені рішенням суду в інших видах судочинства та категоріях справ).

KAC України визначає обставини, що потрібно доводити, й обставини, які доводити не потрібно, тобто преюдиційні. Обставини, установлені судовим рішенням в адміністративній, цивільній або господарській справі, що набрало законної сили, не доказуються під час розгляду інших справ, у яких беруть участь ті самі особи або особа, щодо якої встановлено ці обставини [11].

Загалом преюдиція є похідною категорією від фактичної презумпції істинності судового рішення. Рішення суду як найважливіший акт правосуддя покликане забезпечити захист гарантованих Конституцією України прав і свобод людини та здійснення проголошеного Основним Законом принципу верховенства права [11]. Саме тому обставини, висловлені судом у мотивувальній частині рішення, що набрало законної сили, разом із висновками суду повинні вважатися істинними, адже, якщо встановлені в певному рішенні обставини не визнаються або оспорюються, під сумнів ставиться й саме рішення суду, що є неможливим, виходячи із самої правової природи судового рішення.

Учасники адміністративного процесу звільнені від надання доказів на підтвердження обставин, які встановлені судом під час розгляду іншої адміністративної, цивільної чи господарської справи. Натомість такі учасники мають право посилатися на зміст судового рішення у відповідній справі, що набрало законної сили, у якому ті обставини зазначені як установлені [11]. 


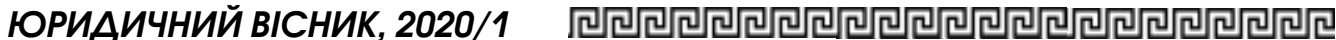

Водночас передбачене ч. 1 ст. $72 \mathrm{KAC}$ України звільнення від доказування не має абсолютного характеру й не може сприйматися судами як неможливість спростування під час судового розгляду обставин, які зазначені в іншому судовому рішенні. Адміністративні суди не повинні сприймати як обов'язкові висновки щодо фактичних обставин справи, наведені в чинних судових рішеннях 3 інших адміністративних, цивільних чи господарських справ. Для спростування преюдиційних обставин, передбачених ч. 1 ст. 72 КАС України, учасник адміністративного процесу, який ці обставини заперечує, повинен подати суду належні та допустимі докази. Вони мають бути оцінені судом, що розглядає справу, у загальному порядку за правилами ст. 86 KAC України. Якщо суд дійде висновку, що обставини у справі, що розглядається, є інакшими, ніж установлені під час розгляду іншої адміністративної, цивільної чи господарської справи, справу належить вирішити відповідно до тих обставин, які встановлені безпосередньо судом, який розглядає справу $[1 ; 11]$.

Отже, адміністративний суд під час розгляду конкретної справи на підставі встановлених ним обставин (у т. ч. преюдиційних) має самостійно кваліфікувати поведінку особи й дійти власних висновків щодо правомірності такої поведінки з відповідним застосуванням необхідних матеріально-правових норм [2].

Однією 3 підстав звільнення від доказування може стати вирок чи ухвала суду про звільнення особи від відповідальності. У певних категоріях справ (наприклад, що стосуються порушень правил торгівлі) застосування преюдиції залежить від особи порушника: якщо порушення здійснив сам приватний підприємець і його притягнуто до відповідальності, це рішення застосовується як преюдиція, а якщо порушення здійснив найманий працівник і його притягнуто до відповідальності, преюдиція не застосову- ється. Коли справа стосується спору між підприємством і податковим органом про правомірність донарахування податкових зобов'язань, обов'язок доведення порушення покладається на податковий орган, проте на підприємство також покладається обов'язок доведення в суді сумлінного виконання податкових зобов'язань і вимог Податкового кодексу України в частині належного ведення бухгалтерського обліку.

$\mathrm{y}$ таких випадках суд змушений ухвалювати рішення на користь особи, оскільки представник державного органу не навів докази. Варто відзначити, що саме в таких випадках представники державних органів часто ігнорують обов'язок доказування з об'єктивних причин (велика завантаженість, постійні реорганізації тощо). Під час судового спору недостатньо заперечити докази представника державного органу, потрібно ще й навести докази того, що вони зібрані з порушенням норм законодавства або не відповідають фактичним обставинам справи. Правова позиція в суді представника особи має бути активною, інакше отримати позитивне рішення суду буде проблематично [10].

Отже, головними дискусійними моментами процесу доказування в адміністративному судочинстві, на нашу думку, є:

1) визначення особливостей доказування в адміністративному судочинстві;

2) визначення порядку надання доказів учасниками адміністративного процесу;

3) витребування доказів судом;

4) забезпечення доказів;

5) правила оцінювання, закріплення доказів і визначення предмета доказування.

У наукові статті автором акцентовано увагу на актуальних питаннях визначення доказів в адміністративних судах. Відзначено, що під час вивчення матеріалів справи адміністративний суд може з влас- 
ної ініціативи витребувати докази, які не надані стороною відповідача, а позивач не має змоги самостійно їх отримати та надати суду.

Предметом доказування є обставини, які підтверджують заявлені вимоги чи заперечення або мають інше значення для розгляду справи й підлягають установленню під час ухвалення судового рішення. Водночас до обставин, що не підлягають доказуванню, зараховано преюдиційні обставини; обставини, які визнаються сторонами процесу; загальновідомі факти та безспірні обставини (обставини, установлені рішенням суду в інших видах судочинства й категоріях справ).

КАС України визначае обставини, щзо потрібно доводити, й обставини, які доводити не потрібно, тобто преюдиційні. Обставини, установлені судовим рішенням в адміністративній, цивільній або господарській справі, що набрало законної сили, не доказуються під час розгляду інших справ, у яких беруть участь mi самі особи або особа, щзодо якої встановлено изі обставини. Обставини, висловлені судом у мотивувальній частині рішення, що набрало законної сили, разом із висновками суду повинні вважатися істинними.

Учасники адміністративного процесу можуть бути звільнені від надання доказів на підтвердження обставин, які встановлені судом під час розгляду іншої адміністративної, цииільної чи господарської справи. Однією з підстав звільнення від доказування може стати вирок чи ухвала суду про звільнення особи від відповідальності.

Головними дискусійними моментами процесу доказування в адміністративному судочинстві, на нашу думку, є: 1) особливості доказування в адміністративному судочинстві; 2) визначення порядку надання доказів учасниками адміністративного процесу; 3) витребування дока- зів судом; 4) забезпечення доказів; 5) правила оцінювання, закріплення доказів і визначення предмета доказування.

Ключові слова: адміністративний суд, провадження, докази, доказування, преюдиція.

Vinnytskyi O. Actual problems of evidence and process of evidence in administrative judiciary

In this scholarly article, the author focuses on the pressing issues of determining evidence in administrative courts. It was noted that when examining the case file, the administrative court may, on its own initiative, require evidence that was not provided by the defendant, and the plaintiff is not able to independently obtain it and provide it to the court.

The subject matter of the evidence is the circumstances, which confirm the stated claims or objections or have other significance for the consideration of the case and are subject to determination when adjudicating. At the same time, the following circumstances are not subject to proof: preliminary circumstances; circumstances recognized by the parties to the process; well-known facts and indisputable circumstances (circumstances established by a court decision in other types of court proceedings and categories of cases).

The Code of Administrative Procedure of Ukraine defines the circumstances that need to be proving and the circumstances that do not need to be proving, i.e. preliminary. Circumstances established by a court decision in an administrative, civil or commercial matter, which have entered into force, shall not be providing by consideration of other cases involving the same person or person in respect of whom the circumstances have been established. The circumstances stated by the court in the reasoning part of the decision that came into force together with the court's findings should be considered true. 


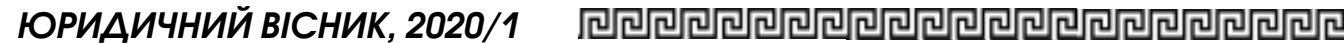

Participants in the administrative process may be exempted from providing evidence to support circumstances established by the court in the consideration of another administrative, civil or commercial case. One of the grounds for exemption may be a sentence or a court order releasing a person from liability.

Themaindiscussionpointsof theprocess of proving in administrative proceedings, in our opinion, are: 1) peculiarities of proving in administrative proceedings; 2) determining the procedure for giving evidence to the participants in the administrative process; 3 ) requesting evidence by court; 4) providing evidence; 5) rules of assessment, consolidation of evidence and determination of the subject of evidence.

Key words: administrative court, proceedings, evidence, evidence, judgment.

\section{Література}

1. Кодекс адміністративного судочинства України : Закон України від 6 липня 2005 року № 2747-IV. Відомості Верховної Ради України. 2005. № 35-36, 37. Ст. 446.

2. Кравцов I., Новаковський П. Актуальні проблеми адміністративного судоuинства. URL: https://radako.com.ua/ news / aktualni-problemi-administrationogosudochinstva.
3. Колпаков В.К., Гордєєв В.В. Настільна книга професійного судді при розгляді адміністративних справ : науково-практичнии посібник для судді. Харків : Харків юридичний, 2011. $476 \mathrm{c}$.

4. Окрема думка судді КС України Маркуш М.А. стосовно Рішення Конституиійного Суду України від 29.08.2012 № 16-pn/ 2012. URL: http:zakon3.rada.gov.ua/laws/ show/n16d710-12/paran2\#n2.

5. Ведель Ж. Административное право Франции. Москва : Прогресс, 1973. 512 с.

6. Брэбан Г. Франиузское административное право. Москва: Прогресс, 1988. 488 c.

7. Салищева Н.Г. Административная юстищия, административное судопроизводство. Москва : Акад. правовой ун-т, 2001. 67 c.

8. Колушко І.Б., Куйбіда Р.О. Адміністративна юстиція: європейський досвід $i$ пропозиції для України. Київ : Факт, 2003.

9. Коліушко І.Б. Виконавча влада та проблеми адміністративної реформи в Україні : монографія. Київ : Факт, 2002. 260 с.

10. Про тягар доказування в адмініcmpaтивному cnopi. URL: https: //lhs.net. ua/ru/ua-dokaz-v-administratyonomu-sporitema-lektsii-vitaliia-shchavinskoho-ru-protiahar-dokazuvannia-v-administratyvnomuspori-rozpoviv-slukhacham-legal-high-schoolzastupnyk-holovy-kyivskoho-okruzhnoho/.

11. Кравизов I., Новаковський П. Актуальні проблеми адміністративного судочинства. URL: https:// radako.com.ua/ news / aktualni-problemi-administrationogosudochinstva. 